\title{
Babbitt: A Novel of Initiation
}

\author{
Aoshuang Yang ${ }^{1, *}$ \\ ${ }^{1}$ School of Foreign Languages \& Cultures, Sichuan University, Chengdu, Sichuan 610065, China \\ "Corresponding author. Email: yiyou0707@163.com
}

\begin{abstract}
The masterpiece of Sinclair Lewis Babbitt was the first novel in America that won the Nobel Prize. Although there are already a large amount of studies on the novel, most of them focused on the commercial culture it reflects. From the perspectives of archetype theory and initiation story, this paper makes its concentration on the protagonist Babbitt, analyzing the five stages of the initiation progress of Babbitt from ignorance to maturity. In doing so, this paper attempts to resolve the controversial problem aroused by the characterization of Babbitt.
\end{abstract}

Keywords: Babbitt, initiation, archetype

\section{INTRODUCTION}

Sinclair Lewis was the first American Nobel Laureate in Literature, writing altogether 22 novels, 125 short stories, and a number of essays, plays as well as journalistic articles. Though he was generally recognized as a landmark in the history of American literature, Lewis has always been linked to one single decade, that is, the 1920s. During the ten years, Lewis published his five most known works - Main Street (1920), Babbitt (1922), Arrowsmith (1925), Elmer Gantry (1927), Dodsworth (1929). As what C. Hugh Holman remarked, "Few American writers have had a greater impact on their world than Lewis during his ten great years, 1920-29" (Holman, 516). Creating the household terms including "Babbitt", "Babbittry", "Babbittism", "Babbittisms", the novel Babbitt gives a graphic and vigorous explanation of that decade. As one of the most well-known novels, Babbitt has been broadly studied by scholars from various angles. Mostly, Babbitt is regarded as a classic example of social satire, reflecting the commercial culture of America in the 1920s. Also, there have been some researches concentrating on the protagonist Babbitt. Such researches treat him as a stagnant character who merely grows two years of age when the novel ends because he returns to his old life. However, the textual facts suggest the more than that. In addition to physical growth of age, Babbitt in fact undergoes extremely important changes beneath the surface. Therefore, this paper will discuss the spiritual growth of Babbitt, from the perspective of initiation story.

\section{CONTROVERSIES ON BABBITT}

Despite the fact that Babbitt was a huge commercial success, through which Lewis gained a large amount of wealth and a rapidly growing reputation in Europe, the book also caused widespread controversies, especially in America. Some critics spoke highly of it. For instance, Paula Kepos said, "A classic example of early twentiethcentury American social satire, Babbitt is usually considered Lewis's most significant novel... Lewis's portrait of Babbitt, however, is complex enough to transcend the limitations of pure satire" (Kepos, 199). Nevertheless, the majority of critics criticized the novel for its lack of thematic coherence. In their opinion, Lewis, with his mixed emotion concerning the middle class, creates a character with conflicting characteristics. "On the one hand... Lewis seems to be condemning Babbitt as a cultural archetype while, on the other, sympathizing with him as an individual" (Kepos, 200). One example is Frederick J. Hoffman who pointed out, "It is interesting that Lewis should have made two Babbitts so very distinct from each other. The doubting Babbitt, upon yielding to his temptations, becomes an anti-Babbitt, a rebel and scapegrace, violating the social, political, and sexual taboos, and for a while taking pleasure in his defiance" (Hoffman, 215). However, if viewing from a different point of view, namely the aspect of individual initiation, Babbitt is not a mixture of two kinds of conflicting characteristics but an entire person who undergoes a significant spiritual growth Therefore, this paper will discuss how Babbitt accomplishes his spiritual transformation and how he fails in realizing his dreams. 


\section{ARCHETYPAL INITIATION}

An initiation story is a story with a theme of growth of one or several characteristics, telling about his, her, or their progresses of growth (Rei Yuping, 7). Generally, there are two types of initiation story. One depicts initiation as "a passage of the young from ignorance about the external world to some vital knowledge. The second describes initiation as an important self-discovery and a resulting adjustment to life or society" (Marcus).

Among the several sources, the legend of heroic adventures is an archetype of initiation story. According to Northrop Frye, the general form of heroic adventure is a description of how a hero achieves rebirth after he has been trapped in darkness and dangers. The hero must fight against a dark dragon which defends a large amount of treasures or threatens a maiden. Always, he is accompanied with a fellowman who resembles much the hero himself. Meanwhile, a warlock who is usually represented by an old woman or a loyal beast will give him suggestions. Then after experiencing some dangerous situations, the hero kills the evil dragon and wins the bride, or both. Thus a brief pattern of the hero's adventure can be generalized as: being away from home - test saving someone else - victory.

\section{BABBITT'S PROCESS OF INITIATION}

Babbitt tells about the life of the mid-aged middle-class businessman Babbitt. He goes through a similar way as the heroes in legendary adventures. In the hero's journey to fulfill his mission, he encounters a variety of dangers and gets advices from his fellowmen or some animals. On his way of initiation, Babbitt meets difficulties and is guided by his friends. In the end, the hero successfully accomplishes his task and wins the bride, or the treasures, or both. For Babbitt, he finally achieves epiphany. In the following, five aspects will be discussed to illustrate the initiation of Babbitt.

\section{A. Temptation}

Heroes in legends usually depart their home for such sublime missions as to save a maiden threatened by some dark force or to find a treasure to save the country. For Babbitt, what tempts him is individual freedom and his desire to escape from the hypocritical world. The opening chapters describe the dull life of Babbitt. His conductions conform to the standard of the middle class. He is waked up by the "nationally advertised and quantitatively produced alarm-clocks" (Lewis 4); he lives in a house which "all houses on Floral Heights" (5); he wears "a standard suit" (9); he drives a standard car; he joins standard clubs; he goes to a standard religion; he holds standard banquets; he expresses standard ideas. In a word, everything is standardized and must conform to the standard, or punishments will come. The conformist culture suffocates him. It is reflected in his dream of the fairy child who is loaded with two senses. First, she represents Babbitt's subconscious desire to escape from the reality in which he must conform to the middle-class standard and gives up his individuality. Second, she is a symbol of his looking forward to true love. Though Myra is a good wife, Babbitt has never loved her. When meeting 24 years ago, Babbitt only regarded Myra as a close friend to dismiss his temporary loneliness from the transient absence of Paul who was enamoured by Zilla. For Babbitt, his relationship with Myra was based on responsibility instead of love. In reality, his middle-class morality does not allow him to pursue true love. So he pursues it in dreams where the fairy child is the symbol of his ideal love. Despite the fact that Babbitt feels his life a disappointment, it comes to him vaguely. The temptation of achieving freedom and love becomes clear after a talk with Paul. And his desire to escape has grown stronger and stronger since Paul has made the suggestion of a trip to Maine.

\section{B. Wandering}

Like the heroes' departure from home at the beginning, Babbitt committed two trips. For the first time, he follows Paul's advice to go to Maine. He enjoys four or five days' freedom in the peaceful Nature. This is a transient extrication for him. On his way home, he believes that "he was a changed man. He was converted to serenity" (Lewis, 168). Yet his decision to change soon fades due to his weak will. After a short while, he embraces his oldfashioned life and gains much more fame and wealth than ever before. But soon he is informed that Paul has been arrested for shooting his wife. $\mathrm{He}$ is extremely astounded and restarts to doubt life. He feels the life without Paul is empty and the world without Paul is meaningless. When he sees Paul in the prison, he understands that the Paul he has loved is dead. To recover the spirit of Paul, he goes to Maine for a second time.

\section{Confusion}

Babbitt bids farewell to his families, planning to break off all relations with the meaningless oldfashioned life and to search the spirit of Paul from the fresh nature. However, the nature disappoints him. "Neither in his voiceless cabin, fragrant planks new-cut pine, nor along the lake, nor in the sunset clouds which presently eddied behind the lavendermisted mountains, could Babbitt find the spirit of Paul as a reassuring presence" (Lewis, 325). He feels lonely. Hour after hour, "he was lonelier than he had ever been in his life" (Lewis, 328). And at the very time he feels the terrible loneliness, and 
the fragments of his old life in Zenith continually assail him. Suddenly, he comprehends that he is so deeply obsessed with the old life that it's already impossible for him to escape from it. Zenith has become a part of him. He can never run away from himself. Therefore, he can never run away from the city which represents his old life. "He knew that he has slinking back not because it was that he longed to do but because it was all he could do" (Lewis, 329).

\section{Guides}

On his way to accomplish his task, the hero is often offered one or more advisers, usually an old woman or a wild animal. For Babbitt, the guides on his way of initiation are his two friends, Paul Riesling and Seneca Doane. As Clark mentions, Babbitt "projects on Paul, and values in Paul, those characteristics which Zenith scorns" (Clark, 244). From Paul Babbitt learns about the truth of his life. It is after the talk with Paul that he knows the exact problems of his life. Paul points out directly that the essence of the businesses they are doing is to "cut each other's throats and make the public pay for it" (Lewis, 70). He also tells Babbitt that their fellowmen who "seem to perfectly content with their home-life and their businesses, and that boost Zenith and the Chamber of commerce" are actually living an unhappy life (Lewis, 70-1). For years, Paul has provided spiritual guidance for Babbitt. That's why when Paul is taken prison Babbitt is so uneasy. He loses his spiritual guides and feels lost. Next, Seneca leads Babbitt to take action to fight against the conformist culture. He reminds Babbitt of his dreams in college days that "he was going to be a lawyer, and take the cases of the poor for nothing, and fight the rich" (Lewis, 331). What Doane influences Babbitt the most is the idea to be liberal, which stimulates the latter to behave rebelliously in his later life.

\section{E. Epiphany}

Usually, the hero finishes his mission by his victory over the dark force or by winning his rewards. For Babbitt, the mark of his essential transformation from ignorance to maturity lies in his epiphany. Following the advice of Seneca, Babbitt initiates his way of identifying himself and achieving individual freedom. He is determined to do what he likes and to express his thoughts freely. To find love, he has an affair with a widow. And he shows some degree of sympathies to the workers. Moreover, he refuses to join the Good Citizens' League. Though Babbitt rebels after his trip with Paul to Maine, he has not considered the consequence. But now he feels the punishment, i.e., being isolated or even deserted by others. His wife is fretted with his "incredible" behaviors; his fellowmen keep at a distance from him; his business partner quits their relationship and cooperates with his competitor; his father-in-law harshly blames him; his favorite employee resigns. $\mathrm{He}$ is frightened, and eventually learns that the social habitual force is too strong to fight against. Living within the society, everyone has to conform to its standard. If anyone who dares to violate the rule, he will be severely punished. Therefore, Babbitt adjusts himself to the rule of Zenith by compromising. He yields to his old life which is meaningless and hypocritical but stable and comfortable. However, he is not completely desperate for he projects his hope upon his son by urgently encouraging him to do what he wants to at the end of the novel.

\section{CONCLUSION}

As discussed above, the novel depicts the initiation of Babbitt. His five intiational stages of Temptation, Wandering, Confusion, Guides, and Epiphany are actually the virulent forms of the archetypal heroic adventures. Thus it is safe to say that Babbitt is an initiation story. Moreover, it should be emphasized that though Babbitt grows mature through the progress of being tempted, wandering, feeling confused, and acquiring epiphany with the help of his two spiritual guides, his initiation turns to be a failure. Even if he realizes the evils of his society and makes some efforts to fight against it, he does not insist on rebelling when his interests are threatened. And therefore, he fails to achieve what he has dreamed of, namely individual freedom, self-identity, and ideal love. After a short moment of rebelling, he embraces the old meaningless but comfortable life immediately when the chance is offered to him, becoming a member of the conformist culture again. It is his lack of sufficient courage and strength that leads his failure and placing hopes on his son, the younger generation.

\section{References}

[1] Clark, Walter H., Jr.. "Aspects of Tragedy in 'Babbitt'." Twentieth-Century Literary Criticism. Ed. Paula Kepos. Vol. 39. Detroit: Gale, 1991. 243-247.

[2] Hoffman, Frederick F.. "The Text: Sinclair Lewis's 'Babbitt'." Twentieth-Century Literary Criticism. Ed. Paula Kepos. Vol. 39. Detroit: Gale, 1991. 213-216.

[3] Kepos, Paula. "Sinclair Lewis." Twentieth-Century Literary Criticism. Ed. Paula Kepos. Vol. 39. Detroit: Gale, 1991. 199-258

[4] Holman, C. Hugh. "Lewis, (Harry) Sinclair." Reference Guide to American Literature. Ed. Thomas Riggs. Detroit: St. James Press, 2000. 515-517.

[5] Lewis, Sinclair. Babbitt. New York: Bantam Dell, 2007.

[6] Marcus, Modecai. "What Is an Initiation Story?." The Journal of Aesthetics and Criticism 19.2(1960): n. pag. Web. 5 June 2012.

[7] Rei, Yuping. An Study on American Initiation Stories. Beijing: China Social Sciences Publishing House, 2004. 